\title{
Chemical Characterization and Anti-Microbial Evaluation of the Eastern Nigerian Specie of African Mistletoe (Loranthus micranthus) Sourced From Citrus sinensis
}

\author{
Johnson-Ajinwo OR* and Nyodee Dummene Godwin \\ Department of Pharmaceutical/Medicinal Chemistry, Faculty of Pharmaceutical Sciences, University of Port Harcourt, Nigeria
}

${ }^{\star}$ Corresponding author: Johnson-Ajinwo OR, Department of Pharmaceutical/Medicinal Chemistry, Faculty of Pharmaceutical Sciences, University of Port Harcourt, Nigeria; E-mail: okiemute_2002@yahoo.co.uk

Received: March 24, 2021; Accepted: March 30, 2021; Published: March 31, 2021

\begin{abstract}
This present study is aimed at determining phytochemical constituents with the aid of GCMS technique and in vitro screening of crude methanol extract of the leaves of Loranthus micranthus Linn parasitic on Citrus sinensis tree sourced from Nsukka, in the eastern part of Nigeria for their antimicrobial activity against six human pathogens. Preliminary phytochemical screening was carried out on the crude extract. The results of the phytochemical analysis showed positive for tannins, flavonoids, steroids, alkaloids, triterpenes/sterols, glycosides and saponins. GCMS analysis revealed nine bioactive compounds in the crude methanol extract of Loranthus micranthus, which includes; Benzoic acid, 3,4,5-trimethoxy-, trimethylsilyl ester, 1,3,5-Triazine, 2,4,6-tris[(trimethylsilyl)oxy]-, Gallic acid, Beta-Amyrin, Beta-Sitosterol, Lup-20(29)-en-3-one. The crude methanol extract of Loranthus micranthus was subsequently partitioned into four solvents to obtain n-hexane, chloroform, ethyl acetate and methanol fractions respectively. The crude extract and the four fractions were observed for antimicrobial activities on the following pathogens; Escherichia coli, Pseudomonas aeruginosa, Bacillus subtilis, Aspergillums niger, Staphylocoocus aureus and Candida albicans at various concentrations using agar diffusion method. The results of the antimicrobial activity proved the ability of the crude methanol extract and the obtained fractions of Loranthus micranthus to inhibit these pathogens. Different bacterial species and fungi exhibited different sensitivities with variable extent towards the extract/fractions. The order of activity against selected bacteria was Candida albicans> Bacillus subtilis $>$ Staphylococcus aureus $>$ Escherichia coli. Only the crude methanol extract at a concentration of $25 \mathrm{mg} / \mathrm{ml}$ inhibited Pseudomonas aeruginosa. While Aspergillums niger was resistant to both the extract and fractions. The n-hexane and the methanol fractions of Loranthus micranthus exerted maximum antimicrobial activity against Candida albicans with an MIC of 1.25 and $0.625 \mathrm{mg} / \mathrm{ml}$ respectively. An indication that the plant possesses very potent antifungal activities The MIC for Bacillus subtilis was 1.25 for $\mathrm{n}$-hexane and methanol fractions respectively. There is good evidence that the plant is more active against gram positive bacteria.
\end{abstract}

Keywords: Antimicrobial, Gas chromatography-Mass spectrometry analysis, Loranthus micranthus Linn, Phytochemical

\section{Introduction}

Citrus sinensis belongs to the Rutaceae family, commonly known as sweet orange, which is a much sought after fruit worldwide with immense cultural and historical significance. The fruit's origin dates back to its mention in the Chinese literature of $314 \mathrm{BC}$ [1]. Orange trees thrive in both tropical and subtropical climates, making the plant; one of the most cultivated globally [2]. In the last decade, sweet orange accounted for $70 \%$ of the citrus fruits cultivated [2]. Currently, the production of oranges has hit 73 million tonnes, with Brazil, China and India leading in the production of oranges [3]. The fruit is a major source of vitamin $\mathrm{C}$, which led to the massive cultivation of oranges along trade routes of European sailors in the discovery age. There has been numerous reports on the bioactivities of sweet oranges by many scholars. The anti-oxidant activities have received immense attention; similarly, the antimicrobial activities of the essential oil, the juice and the peels have equally been documented. However, the bioactivity of the mistletoes parasitic on oranges has very scanty reports, owing to the obvious fact that orange tree rarely bear host to parasitic plants such as mistletoe. A literature search revealed that the anti-microbial activities of Loranthus micranthus from Citrus sinensis has not been carried out, despite the plethoral of anti-microbial activities attributed to Citrus sinensis. While the mistletoes of many host trees such as Pentaclethra macrophylla, Persea americana, Kola nitida, Kola acuminata and Hevea brasiliensis have been investigated and shown to possess numerous activities, which includes: antioxidant, antimicrobial, antidiarrhoeal, immunomodulatory, antidiabetic, antihypertensive, and hypolipidemic activities [4]. The Citrus sinensis mistletoe has not been investigated.

In my previous work, it was observed that mistletoes parasitic on the host trees with significant bioactivity possessed some of the reported activities of their host trees. While the mistletoes parasitic on the host trees with few significant bioactivities also showed less significant bioactivities [5]. In this current work, the chemical characterization and antimicrobial evaluation of Loranthus micranthus (LM) parasitic on Citrus sinensis is reported. 


\section{Materials and Methods}

\section{Plant Material}

Fresh leaves of LM parasitic on Citrus sinensis were obtained in Oba in Nsukka LGA of Enugu State. The plant was identified by a botanist in the Department of Botany, University of Nigeria, Nsukka, after which a voucher specimen was deposited in the department.

\section{Extraction Procedure}

The LM leaves were dried at room temperature under a shade, and pulverized. Weighed quantities of the LM were extracted with aqueous methanol using soxhlet extractor. The obtained methanol extract was subsequently partitioned into the following four solvents: $\mathrm{N}$-hexane, Chloroform, Ethyl acetate and Methanol sequentially.

\section{Preliminary Screening}

The phytochemical constituents of the methanol extracts were determined according to the method prescribed by Trease and Evans [6].

\section{GC-MS Analysis of the Crude Extracts}

The gas chromatography mass spectrometry (GC-MS) analysis of the crude methanol extract of the leaves of Loranthus micranthus parasitic on $C$. sinensis was quantitatively determined using an Agilent 7890B GC system coupled with an Agilent 5977A MSD with a Zebron-5MS column (ZB-5MS $30 \mathrm{~m} \times 0.25 \mathrm{~mm} \times 0.025 \mu \mathrm{m}$ ) (5\%-phenylmethylpolysiloxane). The GC-grade helium served as the carrier gas at a constant flow rate of $2 \mathrm{~mL} / \mathrm{min}$. The crude extract was dissolved with ethanol and filtered before use. The column temperature was maintained at $60^{\circ} \mathrm{C}$ and gradually increased at $10^{\circ} \mathrm{C}$ per minute until a final temperature of $300^{\circ} \mathrm{C}$ was reached. The time taken for the GC-MS analysis was $30 \mathrm{~min}$. The compounds were identified based on computer matching of the mass spectra with the NIST 11 MS library (National Institute of Standards and Technology library).

\section{Materials for Anti-microbial Assay}

Equipment: Microscope, autoclave, incubator, wire loop, Bunsen burner, markers, petri dish test tubes and McCartney bottle.

\section{Reagents}

Nutrient agar and broth, Sabourand's dextrose agar and broth, dimethyl sulfoxide (DMSO), sterile distilled water.

\section{Test Organisms}

All organisms used were clinical isolates obtained from the laboratory of pharmaceutical microbiology, University of Port Harcourt. The research utilized two gram positive bacteria, two gram negative bacteria and two fungi. The organisms were; Escherichia coli, Pseudomonas aeruginosa, Bacillus subtilis, Aspergillums niger, Staphylocoocus aureus and Candida albicans. The organisms were sub cultured and standardized before use.

\section{Anti-Microbial Assay Method}

Agar diffusion by cup plate method was adopted as described [7]. The entire agar used was prepared according to the manufacturer's specification. The glass wares were thoroughly washed and sterilized, suspensions of the test organisms were made and $0.05 \mathrm{ml}$ of $0.5 \mathrm{McF}$ arland standard of the test organism concentration were dispensed each in the plate and $20 \mathrm{ml}$ of the sterile molten agar each were added, mixed and allowed to set/gel, using two fold serial dilution. Different concentration of the methanol extract, the fractions and standard antibiotic used were made. Holes were bored on the agar using cock bore and labeled properly. $0.05 \mathrm{ml}$ of each concentration was added into the respective holes with the aid of sterile syringe and allowed to diffuse for 15-20 minutes, then incubated at $37^{\circ} \mathrm{C}$ (bacterial), $25^{\circ} \mathrm{C}$ (fungi) for 24 hours. The zone of inhibition was determined against concentration with the aid of a meter rule to the nearest millimeter. Positive control for bacteria was Ciprofloxacin $100 \mathrm{mg} / 100 \mathrm{ml}$. Ketoconazole at a dose of $100 \mathrm{mg} / \mathrm{ml}$ served as the positive control for the fungi. The extract and fractions were solubilized in DMSO. A concentration of $50 \mathrm{mg} / \mathrm{ml}$ of the plant extracts were used for the antimicrobial assay. This concentration was serially diluted seven times to yield a minimal concentration of $0.78125 \mathrm{mg} / \mathrm{ml}$. The MIC of the fractions which showed activity, were determined using the already diluted concentrations, $10 \mathrm{mg} / \mathrm{ml}, 5 \mathrm{mg} / \mathrm{ml}, 2.5 \mathrm{mg} / \mathrm{ml}, 1.25$ $\mathrm{mg} / \mathrm{ml}, 0.625 \mathrm{mg} / \mathrm{ml} 0.3125 \mathrm{mg} / \mathrm{ml}$ and $0.15625 \mathrm{mg} / \mathrm{ml}$. The MIC was obtained as the least concentration that had a zone of inhibition.

\section{Statistical Analysis}

Each test was carried out in triplicate. The values were expressed as mean \pm standard error of mean (SEM). The Dunnett one way analysis (ANOVA) was used to determine the significant differences among all columns against control and the $P$ value $<0.05$ was considered as significant. All statistical analysis was performed using Graph Pad Prism version 8.0 software.

\section{Results}

Table 1 shows the result of phytochemical analysis of the crude methanol extract of LM. The pharmacologically important classes of secondary metabolites are contained in the mistletoe. There is a heavy

Table 1: Results from the Phytochemical Screening.

\begin{tabular}{|c|c|}
\hline Phytochemical Constituents & Qualitative Assessment \\
\hline $\begin{array}{c}\text { Flavonoids } \\
\text { Shinoda Reduction Test }\end{array}$ & ++ \\
\hline $\begin{array}{c}\text { Saponins } \\
\text { Frothing Test }\end{array}$ & ++ \\
\hline $\begin{array}{c}\text { Tannins } \\
\text { Ferric chloride test }\end{array}$ & ++ \\
\hline $\begin{array}{c}\text { Alkaloids } \\
\text { Mayer's test }\end{array}$ & + \\
\hline $\begin{array}{c}\text { Proteins } \\
\text { Million's Test }\end{array}$ & + \\
\hline $\begin{array}{l}\text { Fats and oil } \\
\text { Oil Stain test }\end{array}$ & + \\
\hline $\begin{array}{l}\text { Terpenoids/Sterols } \\
\text { Salkwoski's Test }\end{array}$ & + \\
\hline $\begin{array}{l}\text { Carbohydrates } \\
\text { Molisch test }\end{array}$ & + \\
\hline $\begin{array}{c}\text { Glycosides } \\
\text { Keller-killiani } \\
\end{array}$ & + \\
\hline $\begin{array}{l}\text { Reducing sugar } \\
\text { Fehlings test }\end{array}$ & + \\
\hline $\begin{array}{c}\text { Resins } \\
\text { Copper acetate solution }\end{array}$ & Trace \\
\hline
\end{tabular}


presence of flavonoids, saponins and tannins in the plant compared to the phytoconstituents. Similarly, the phytochemical analysis of the peels of $C$. sinensis have been documented to possess alkaloid, flavonoids, terpenoids, reducing sugars, saponins, tannins and amino acid [8].

The GCMS chemical characterization of the crude methanol extract was carried out and the results presented in Table 2. Nine compounds were identified from a spectral match with the NIST library of the equipment. There were some unidentified peaks in the GCMS chromatogram, but of the nine identified compounds, some pharmacological-active compounds with antimicrobial activities were recorded.

The antimicrobial activities of the crude methanol extract are disclosed in Table 3. The results showed that the extract had pronounced anti-fungal activity. The results further demonstrated that the extract had less impact on gram negative bacteria in comparison to gram positive bacteria.

The fractions obtained from the crude methanol extract were evaluated for their antimicrobial activities at a lower concentration to determine their potency. These results obtained are presented in Table 4. Significantly, all the fractions had no activity against $P$. aeruginosa and $A$. niger. However, various degrees of inhibitions were recorded against the tested pathogens.

The analysis of the MIC of the crude methanol extract and fractions are portrayed in Table 5. The key observation is that both the crude extract and the fractions exercised antifungal activities against $C$ albicans. Except the crude methanol extract at a concentration of 25 $\mathrm{mg} / \mathrm{ml}$, all the fractions had no activity over P. aeruginosa.

\section{Discussion}

The citrus mistletoe is rich in flavonoids which are known to demonstrate antibacterial, anti-inflammatory and antifungal activities [9]. The presence of phenolic compounds has been attributed to antioxidant activities [10]. Flavonoids have both antifungal and antibacterial activity and anti-inflammatory properties [9]. Similarly, therapeutic benefits from alkaloids [11] and saponins [12] have been documented in literature.

The GCMS analysis of the Crude methanol extract revealed a number of peaks from which nine compounds were identified as Benzoic acid, 3,4,5-trimethoxy-, trimethylsilyl ester; 1,3,5-Triazine, 2,4,6-tris[(trimethylsilyl)oxy]-;Benzoicacid,3,4,5-tris(trimethylsiloxy)-, trimethylsilyl ester (gallic acid); Beta-Amyrin trimethylsilyl ether (Beta-Amyrin); Beta-Sitosterol trimethylsilyl ether (Beta-Sitosterol); Lup-20(29)-en-3-one; Antra-9,10-quinone, 1-(3-hydrohy-3-phenyl-1triazenyl)-; 4-Dehydroxy-N-(4,5-methylenedioxy-2-nitrobenzylidene) tyramine and 2-Thiophenecarboxylic acid, 4-methyl-5-nonadecyl-, methyl ester. It was discovered that the citrus mistletoe contained lupinetype triterpenes which have demonstrated significant cytotoxicities on human leukemias, melanomas and neuroblastomas. One analogueLup-28-al-20(29)-en-3-one, a close structural analogue of Lup-20(29)en-3-one was the most bioactive [13].

Again the presence of gallic acid and its derivative Benzoic acid, 3,4,5-trimethoxy-, trimethylsilyl ester, strongly supports the antimicrobial activity of this mistletoe. Previous studies have documented the antimicrobial activities of gallic acid derivatives on Potato Bacterial Wilt Pathogen with 3,5-dihydroxy-4-methoxybenzoic acid shown to be the most potent one with a MIC value of $0.47 \mathrm{mg} / \mathrm{ml} \mathrm{[14]}$.

Table 2: GCMS Analysis Results.

\begin{tabular}{|c|c|c|c|}
\hline No. & Compounds & Retention time (RT) & $\%$ Peak Area \\
\hline 1 & Benzoic acid, 3,4,5-trimethoxy-, trimethylsilyl ester & 18.061 & 0.64 \\
\hline 2 & 1,3,5-Triazine, 2,4,6-tris[(trimethylsilyl)oxy]- & 18.670 & 1.24 \\
\hline 3 & Benzoic acid, 3,4,5-tris(trimethylsiloxy)-, trimethylsilyl ester (gallic acid) & 19.580 & 9.98 \\
\hline 4 & Beta.-Amyrin trimethylsilyl ether (Beta.-Amyrin) & 27.060 & 3.52 \\
\hline 5 & Beta.-Sitosterol trimethylsilyl ether (Beta.-Sitosterol) & 27.300 & 5.84 \\
\hline 6 & Lup-20(29)-en-3-one & 27.900 & 15.62 \\
\hline 7 & Antra-9,10-quinone, 1-(3-hydrohy-3-phenyl-1-triazenyl)- & 28.990 & 12.18 \\
\hline 8 & 4-Dehydroxy-N-(4,5-methylenedioxy-2-nitrobenzylidene)tyramine & 29.008 & 3.63 \\
\hline 9 & 2-Thiophenecarboxylic acid, 4-methyl-5-nonadecyl-, methyl ester & 29.600 & 2.55 \\
\hline
\end{tabular}

Table 3: Antimicrobial assay result of the crude Methanol extract.

\begin{tabular}{|c|c|c|c|c|c|c|c|}
\hline \multirow{2}{*}{$\begin{array}{l}\text { Methanol extract } \\
\text { Test Organism }\end{array}$} & \multicolumn{7}{|c|}{ Concentration $(\mathrm{mg} / \mathrm{ml}) /$ Diameter of zone of inhibition $(\mathrm{mm})$ (Mean values $\pm \mathrm{SEM})$} \\
\hline & 50 & 25 & 12.5 & 6.25 & 3.125 & 1.5625 & 0.78125 \\
\hline S. aureus & $7.0 \pm 0.0$ & $5.3 \pm 0.3$ & $4.0+0.0$ & + & + & + & + \\
\hline E. coli & $8.0+0.0$ & $6.0+0.0$ & $4.6+0.3$ & $3.0+0.0$ & + & + & + \\
\hline B. subtilis & $9.0+0.0$ & $7.0+0.0$ & $5.0+0.0$ & $4.0+0.0$ & $3.0+0.0$ & + & + \\
\hline P. aeruginosa & $4.0+0.00$ & $2.0+0.0$ & + & + & + & + & + \\
\hline C. albicans & $11.7+0.3$ & $10.0+0.0$ & $8.0+0.0$ & $6.0+0.0$ & $4.0+0.0$ & $2.0+0.0$ & + \\
\hline A. niger & + & + & + & + & + & + & + \\
\hline
\end{tabular}


: Johnson-Ajinwo OR (2021) Chemical Characterization and Anti-Microbial Evaluation of the Eastern Nigerian Specie of African Mistletoe (Loranthus micranthus) Sourced From Citrus sinensis

Table 4: Inhibition Zone Diameter Exhibited By The Fractions At Different Concentrations.

\begin{tabular}{|c|c|c|c|c|c|c|}
\hline \multirow{2}{*}{ Fraction Conc $(\mathrm{mg} / \mathrm{ml})$} & \multicolumn{6}{|c|}{ Test Organisms } \\
\hline & S. aureus & E. coli & B. subtilis & P. aeruginosa & C. albicans & A. niger \\
\hline n-Hexane 10 & $6.0+0.0$ & $5.0+0.0$ & $6.0+0.0$ & + & $7.0+0.0$ & + \\
\hline 5 & $4.0+0.0$ & $3.0+0.0$ & $5.0+0.0$ & + & $5.0+0.0$ & + \\
\hline 2.5 & $3.0+0.0$ & + & $4.0+0.0$ & + & $4.0+0.0$ & + \\
\hline 1.25 & + & + & $3.0+0.0$ & + & $3.0+0.0$ & + \\
\hline 0.625 & + & + & + & + & + & + \\
\hline 0.3125 & + & + & + & + & + & + \\
\hline 0.15625 & + & + & + & + & + & + \\
\hline Chloroform 10 & $4.0+0.0$ & + & $6.0+0.0$ & + & $6.0+0.0$ & + \\
\hline 5 & $2.9+0.1$ & + & $4.0+0.0$ & + & $4.0+0.0$ & + \\
\hline 2.5 & + & + & $2.0+0.0$ & + & $3.0+0.0$ & + \\
\hline 1.25 & + & + & + & + & $2.0+0.0$ & + \\
\hline 0.625 & + & + & + & + & + & + \\
\hline 0.3125 & + & + & + & + & + & + \\
\hline 0.15625 & + & + & + & + & + & + \\
\hline Ethyl acetate 10 & $6.0+0.0$ & $4.0+0.0$ & + & + & $6.0+0.0$ & + \\
\hline 5 & $4.0+0.0$ & $2.3+0.3$ & + & + & $5.0+0.0$ & + \\
\hline 2.5 & + & + & + & + & $4.0+0.0$ & + \\
\hline 1.25 & + & + & + & + & $3.0+0.0$ & + \\
\hline 0.625 & + & + & + & + & $2.0+0.0$ & + \\
\hline 0.3125 & + & + & + & + & + & + \\
\hline 0.15625 & + & + & + & + & + & + \\
\hline Methanol 10 & $4.0+0.0$ & $6.0+0.0$ & $6.0+0.0$ & + & $8.0+0.0$ & + \\
\hline 5 & $2.0+0.0$ & $4.0+0.0$ & $5.0+0.0$ & + & $6.0+0.0$ & + \\
\hline 2.5 & + & $2.0+0.0$ & $4.0+0.0$ & + & $5.0+0.0$ & + \\
\hline 1.25 & + & + & $2.0+0.0$ & + & $3.0+0.0$ & + \\
\hline 0.625 & + & + & + & + & $2.0+0.0$ & + \\
\hline 0.3125 & + & + & + & + & + & + \\
\hline 0.15625 & + & + & + & + & + & + \\
\hline Ciprofloxacin $1 \mathrm{mg} / \mathrm{ml}$ & $11.3 \pm 0.3$ & $17.3 \pm 0.6$ & & $19.7 \pm 0.3$ & + & + \\
\hline Ketoconazole $1 \mathrm{mg} / \mathrm{ml}$ & + & + & + & + & $16.3 \pm 0.3$ & \\
\hline DMSO & + & + & + & + & + & + \\
\hline
\end{tabular}

Ciprofloxacin: Positive control for bacteria; Ketoconazole: Positive control for Fungi; DMSO: Negative control; +: No inhibition.

Table 5: MIC of Crude methanol Extract and Fractions.

\begin{tabular}{|c|c|c|c|c|c|}
\hline \multirow{2}{*}{ Extract/Fraction } & \multicolumn{5}{|c|}{ MIC of Test Organisms } \\
\cline { 2 - 6 } & S. aureus & E. coli & B. subtilis & P. aeruginosa & C. albicans \\
\hline Methanol extract & 12.5 & 6.25 & 3.125 & +25 & 1.5625 \\
\hline n-Hexane fraction & 2.5 & 5 & 1.25 & +25 \\
\hline Chloroform fraction & 5 & + & +.5 & + & 1.25 \\
\hline Ethyl acetate fraction & 5 & 5 & 1.25 & + & \\
\hline Methanol fraction & 5 & 2.5 & + & 0.625 \\
\hline
\end{tabular}

Beta-amyrin ( $\beta$-amyrin), another bioactive compound present in citrus mistletoe has been evaluated on clinical pathogens. The activity when compared with standard drugs was found to be comparable with the standard drug used [15].

$\beta$-sitosterol is the major phytosterols, found abundantly in plants is also present in citrus mistletoes. Many in vitro and in vivo studies have demonstrated various biological actions such as antimicrobial, anti - inflammatory, analgesic, immunomodulatory, anticancer, lipid lowering effect, anxiolytic \& sedative effects, hepatoprotective, protective effect against NAFLD and respiratory diseases. Other effects include: wound healing effect, antioxidant and anti-diabetic activities [16]. The antimicrobial studies of novel series of 2,4-bis(hydrazino)6-substituted-1,3,5-triazine and their Schiff base derivatives was carried using S. aureus, and E. coli among the pathogens evaluated. The 1,3,5-triazine were found to demonstrate significant activity on bacteria in microgram $/ \mathrm{ml}$ range, but no antifungal activity was observed. It may be suggested that the presence of 1,3,5-triazine in the mistletoe contributed to the observed activity against the gram positive bacteria [17].

\section{Conclusion}

The results of the analyses shown earlier have demonstrated that the leaves of L. micranthus Linn parasitic on Citrus sinensis possess very potent antifungal activities against $C$. albicans and thus could be used as a therapeutic preparation in treatment of fungal Infections. Also, from the results the fractions displayed varying degree of antimicrobial activity against $S$. aureus, E. coli and B. subtilis. While $P$. aeruginosa and $A$. niger could not be inhibited by the fractions at the test concentrations. This suggests that the extracts had more activity against gram positive bacteria than against gram negative bacteria. The antimicrobial activity of the citrus mistletoe merits further research as the plant has potentials for development into antimicrobial agent that can be used in treating infections. Again, given that the plant contains some reported antimicrobial compounds, this might be exploited in the design and development fungicidal and bactericidal drugs. 


\section{Conflict of Interest}

No potential conflict of interest was reported by the authors.

\section{References}

1. Xu Q, Chen LL, Ruan X, Chen D, Zhu A, et al. (2013) "The draft genome of sweet orange (Citrus sinensis)". Nature Genetics 45: 59-66. [crossref]

2. “Citrus sinensis" (2017) Germplasm Resources Information Network (GRIN). Agricultural Research Service (ARS), United States Department of Agriculture (USDA).

3. Production, Crops, World Regions (2018) United Nations, Food and Agricultural Organization, FAO Statistics.

4. Moghadamtousi SZ, Hajrezaei M, Abdul Kadir H, Zandi K (2013) Loranthus micranthus Linn.: Biological Activities and Phytochemistry. Evidence-Based Complementary and Alternative Medicine 2013: 273712. [crossref]

5. Osadebe PO, Johnson-Ajinwo OR (2010) A Review of the Bio-Activity Relationship of Mistletoes and the Leaves of their Host Trees. Nigerian Journal of Pharmaceutical Research 8: 145-150.

6. Evans WC, Evans D, Trease GE (2002) Trease and Evans' Pharmacognosy. 15th Edition, Publisher: WB Saunders, Edinburgh ; New York.

7. Seeley HW, Van Denmark PJ (1975) "Microbes in action" in A Laboratory manual of Microbiology. 2nd ed. Bombay: D B. Taraporewala Sons and Co 55-80.

8. Baba J, Mohammed SB, Yảaba Y, Umaru FI (2018) Antibacterial Activity of Sweet Orange (Citrus sinensis) on some Clinical Bacteria Species Isolated from Wounds. J Family Med Community Health 5: 1154
9. Iwu MW, Duncan AR, Okunji CO (1999) New antimicrobials of plant origin. In: Janick J (Ed.), perpectives on New uses. ASHS press Alexandria. VA, 457-462.

10. Gomez-Alonso S, Fregapane G, Salvador MD, Gordon MH (2003) Changes in phenolic composition and antioxidant activity of virgin olive oil during frying. $J$. Agric. Food Chem 51: 667-672. [crossref]

11. Njoku PC, Akumefula MI (2007) Phytochemical and Nutrient Evaluation of Spondias mombin Leaves. Parkistan Journal of Nutrition 6: 613-615.

12. Rabe $\mathrm{T}$, van Staden J (2000) Isolation of an antibacterial sesquiterpenoid from Warburgia salutaris. J. Ethnopharmacol 73: 171-174. [crossref]

13. Keishi H, Kazuyuki H, Hironobu O, Takahashi S (2003) Anti-leukemia activities of Lup-28-al-20(29)-en-3-one, a lupane triterpene. Toxicology Letters 143: 1-7. [crossref]

14. Mohamed A, Farag Dalia A, Al-Mahdy R, El Dine S, Fahmy S, et al. (2015) Structure Activity Relationships of Antimicrobial Gallic Acid Derivatives from Pomegranate and Acacia Fruit Extracts against Potato Bacterial Wilt Pathogen. Chemistry \& Biodiversity 12: 955-962. [crossref]

15. Ogwuche CE, Amupitan JO, Ndukwe IG, Ayo RG (2014) Isolation and Biological Activity of the Triterpene B-Amyrin from the Aerial Plant Parts of Maesobotrya Barteri (Baill). Med chem 4: 729-733.

16. Babu S, Jayaraman S (2020) An update on $\beta$-sitosterol: A potential herbal nutraceutical for diabetic management. Biomedicine \& Pharmacotherapy 131: 110702. [crossref]

17. Al-Rasheed HH, Sholkamy EN, Al Alshaikh M, Mohammed RH, Siddiqui MRH, et al. (2018) Synthesis, Characterization, and Antimicrobial Studies of Novel Series of 2,4-Bis(hydrazino)-6-substituted-1,3,5-triazine and Their Schiff Base Derivatives. Hindawi Journal of Chemistry 2018: 8507567.

\section{Citation:}

Johnson-Ajinwo OR, Godwin ND (2021) Chemical Characterization and Anti-Microbial Evaluation of the Eastern Nigerian Specie of African Mistletoe (Loranthus micranthus) Sourced From Citrus sinensis. Internal Med Res Open J Volume 6(2): 1-5. 